\title{
BDNF-Promoted Increases in Proximal Dendrites Occur via CREB-Dependent Transcriptional Regulation of Cypin
}

\author{
Munjin Kwon, ${ }^{1,2}$ José R. Fernández, ${ }^{1,2}$ Gregory F. Zegarek, ${ }^{1}$ Sean B. Lo, ${ }^{1}$ and Bonnie L. Firestein ${ }^{1}$ \\ ${ }^{1}$ Department of Cell Biology and Neuroscience and ${ }^{2}$ Molecular Biosciences Graduate Program, Rutgers, The State University of New Jersey, New \\ Jersey $08854-8082$
}

\begin{abstract}
Alterations in dendrite branching and morphology are present in many neurodegenerative diseases. These variations disrupt postsynaptic transmission and affect neuronal communication. Thus, it is important to understand the molecular mechanisms that regulate dendritogenesis and how they go awry during disease states. Previously, our laboratory showed that cypin, a mammalian guanine deaminase, increases dendrite number when overexpressed and decreases dendrite number when knocked down in cultured hippocampal neurons. Here, we report that exposure to brain-derived neurotrophic factor (BDNF), an important mediator of dendrite arborization, for $72 \mathrm{~h}$ but not for $24 \mathrm{~h}$ or less increases cypin mRNA and protein levels in rat hippocampal neurons. BDNF signals through cypin to regulate dendrite number, since knocking down cypin blocks the effects of BDNF. Furthermore, BDNF increases cypin levels via mitogenactivated protein kinase and transcription-dependent signaling pathways. Moreover, the cypin promoter region contains putative conserved cAMP response element (CRE) regions, which we found can be recognized and activated by CRE-binding protein (CREB). In addition, exposure of the neurons to BDNF increased CREB binding to the cypin promoter and, in line with these data, expression of a dominant negative form of CREB blocked BDNF-promoted increases in cypin protein levels and proximal dendrite branches. Together, these studies suggest that BDNF increases neuronal cypin expression by the activation of CREB, increasing cypin transcription leading to increased protein expression, thus identifying a novel pathway by which BDNF shapes the dendrite network.
\end{abstract}

\section{Introduction}

Dendrite patterning and development are responsible for determining how input signals are processed in the CNS. The degree of dendrite branching can regulate the electrical properties of a neuron (Miller and Jacobs, 1984), and dendrite development is regulated by intrinsic and extrinsic factors (Landgraf and Evers, 2005; Libersat, 2005). Extrinsic factors can modulate specific patterns of dendrite growth and branching by activating intrinsic cues that directly affect the cytoskeleton or the transcriptional regulation of gene expression (Whitford et al., 2002). Neurotrophic factors play important roles in regulating neurite growth and branching in neurons. The major neurotrophic factors are the neurotrophins: nerve growth factor (NGF) (LeviMontalcini, 1987; Shooter, 2001), brain-derived neurotrophic factor (BDNF) (Barde et al., 1982), neurotrophin-3 (NT-3) (Mai-

Received Dec. 27, 2010; revised May 16, 2011; accepted May 18, 2011.

Author contributions: M.K., J.R.F., and B.L.F. designed research; M.K., J.R.F., G.F.Z., and S.B.L. performed research; M.K., J.R.F., G.F.Z., S.B.L., and B.L.F. analyzed data; M.K. and B.L.F. wrote the paper.

This work was supported in part by a Busch Biomedical Grant, National Science Foundation (NSF) Grants IBN0919747 and IBN-0548543, March of Dimes Foundation Grants 1-FY04-107 and 1-FY08-464, and a Grant-In-Aid from the American Heart Association (to B.L.F.). J.R.F. was supported in part by the IGERT (Integrative Graduate Education and Research Traineeship) Program on Integratively Engineered Biointerfaces at Rutgers: NSF Grant DGE-0333196. M.K. was awarded an Anna B. and James Leathem Fellowship, and G.F.Z. and S.B.L. received School of Arts and Sciences Honors Awards in support of this research. We acknowledge Maxine Chen for some of the pilot studies leading to this work.

Correspondence should be addressed to Dr. Bonnie L. Firestein, Department of Cell Biology and Neuroscience, Rutgers, The State University of New Jersey, Nelson Biological Laboratories, 604 Allison Road, Piscataway, NJ 088548082. E-mail: Firestein@biology.rutgers.edu.

DOI:10.1523/JNEUROSCI.6785-10.2011

Copyright $\odot 2011$ the authors $\quad 0270-6474 / 11 / 319735-11 \$ 15.00 / 0$ sonpierre et al., 1990), and neurotrophin-4/5 (Hallböök et al., 1991). These factors are secreted from neurons and glial cells to exert their effects through the tyrosine receptor kinase (Trk) family in response to neuronal activity (Chao et al., 1992; Levine et al., 1995; Müller et al., 1995). BDNF is one of the most studied extrinsic factors regulating dendrite outgrowth and branching (Segal et al., 1995; McAllister et al., 1996, 1997; Schwartz et al., 1997; Baker et al., 1998; Jin et al., 2003) and increasing proximal dendrite growth and number in pyramidal neurons (McAllister et al., 1995; Baker et al., 1998; Horch et al., 1999).

Cypin (cytosolic PSD-95 interactor) was first identified as a protein that decreases the synaptic localization of PSD-95 (Firestein et al., 1999). Cypin is a guanine deaminase and contains a zinc-binding motif, CRMP (collapsin response mediator protein) homology domain and a PDZ-binding motif (Fernández et al., 2008). Our laboratory has reported that cypin plays an important role in regulating dendrite number in rat hippocampal neurons. Overexpression of cypin results in an increase in dendrite branching, which correlates with cypin's guanine deaminase activity (Akum et al., 2004). Cypin binds directly to tubulin heterodimers and promotes microtubule assembly (Akum et al., 2004), suggesting that cypin regulates dendrite branching via cytoskeletal rearrangement.

Here, we report a novel signaling pathway by which BDNF increases proximal dendrite branching. BDNF activates the mitogen-activated protein kinase (MAPK) signaling pathway, resulting in increased cypin mRNA and protein levels. Furthermore, this increase is only seen after $72 \mathrm{~h}$ of BDNF treatment, suggesting that cypin may mediate the effects of BDNF under 
chronic exposure. We also show that cAMP response element (CRE)-binding protein (CREB) binds to the cypin promoter to increase cypin transcription, and this binding is increased upon exposure to BDNF. Most importantly, we show that BDNF signals through CREB and cypin to increase proximal dendrite number. Our work links an important extrinsic regulator of dendrite branching to an important intrinsic factor that increases dendrite number, further uncovering molecular mechanisms that shape dendrites during development.

\section{Materials and Methods}

Antibodies and reagents. Rabbit polyclonal antibody raised against cypin has been described previously (Firestein et al., 1999). Mouse monoclonal antibody recognizing $\beta$-actin was purchased from Sigma. Mouse anti-MAP2 was from BD-PharMingen, and chicken anti-GFP was purchased from Rockland Immunochemicals. Mouse monoclonal antibody to CREB was from Cell Signaling Technology. Rabbit monoclonal antibodies recognizing phospho-Akt, Akt, phospho-p70S6 kinase, p70S6 kinase, phosphoErk1/2, and Erk1/2 were from Cell Signaling Technology. Cyanine (Cy)2-, Cy3-, and Cy5conjugated secondary antibodies were from Jackson ImmunoResearch. Recombinant human BDNF (rhBDNF), mouse NGF, and U0126 were purchased from Promega, and myristoylated protein kinase A (PKA) inhibitory peptide 14-22 amide, wortmannin, and rapamycin were from Calbiochem/EMD Chemicals. Actinomycin D was purchased from Sigma. PKA kinase activity kit was from Enzo Life Sciences.

RNA interference and DNA constructs. pSuper GFP vector (Oligoengine), containing shRNA against the cypin transcript and an unrelated sequence as a negative control, was used as described previously (Chen and Firestein, 2007). cDNA encoding rat CREB isoform A (NCBI accession no. NM_114443.1) was subcloned into pEGFP-C1 or dsRed2-C1 vector (Clontech Inc.). A dominant negative (DN) mutant of CREB and a constitutively active (CA) mutant of CREB were constructed using the QuikChange II Site-Directed Mutagenesis Kit (Stratagene) following the manufacturer's protocol. The serine 119 residue of CREB was replaced with alanine or aspartate using the primer 5'-CCT TTC AAG GAG GCC TGC CTA CAA GAA AAT CTT GAA TGA CTT ATC-3' or the primer 5'CTT TCA AGG AGG CCT GAC TAC AAG AAA ATC TTG AAT GAC TTA TC-3', respectively.

Primary culture of hippocampal neurons. Neuronal cultures were prepared from hippocampi of rat embryos of either sex at $18 \mathrm{~d}$ gestation as described previously (Firestein et al., 1999). The hippocampi were dissociated, and cells were plated on poly-D-lysine-coated glass coverslips (12 $\mathrm{mm}$ diameter) at a density of 1800 cells $/ \mathrm{mm}^{2}$ or $1 \times 10^{6}$ cells on $35 \mathrm{~mm}$ culture dishes. Cultures were maintained in Neurobasal medium (Invitrogen ) supplemented with B27 (Invitrogen), penicillin, streptomycin, and GlutaMAX (Invitrogen ). Cells were grown for 7 days in vitro (DIV) and used for specific experiments as indicated below.

Western blotting. Hippocampal neurons were plated with $1 \times 10^{6}$ cells per dish. Neurons were treated with neurotrophins, kinase inhibitors, or DMSO vehicle $(0.01 \%$ final concentration) at the indicated concentrations for $72 \mathrm{~h}$. Neurons were washed with ice-cold PBS and lysed in TEE (25 mm Tris-HCl, 1 mm EDTA, 1 mм EGTA, pH 7.4). Cells were further lysed by passing the extract through a 26 gauge needle 20 times, and solubilized using Triton X-100 at a final concen-
B

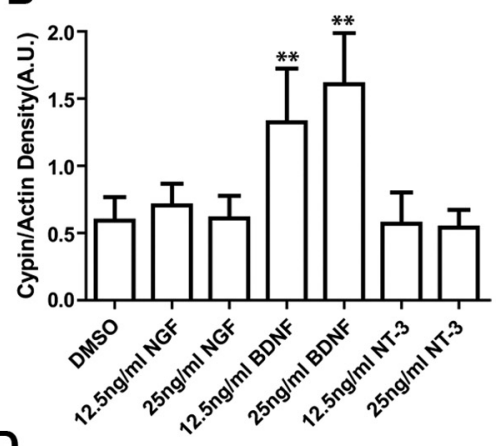

D

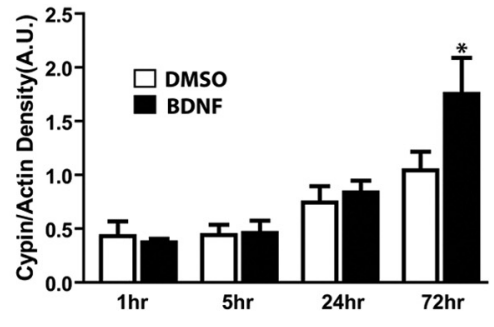


A


B

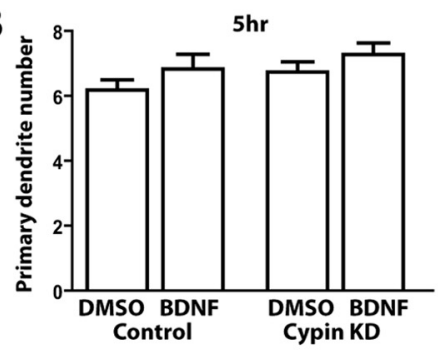

C

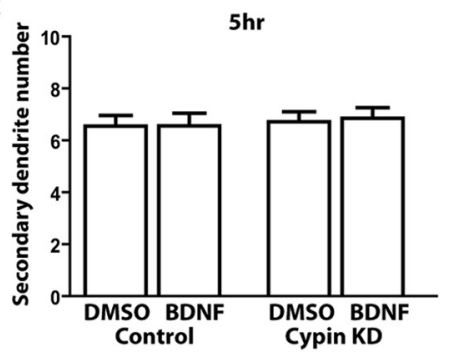

D

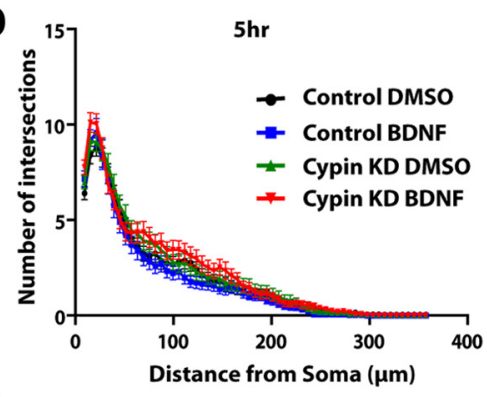

E



DMSO 72hr
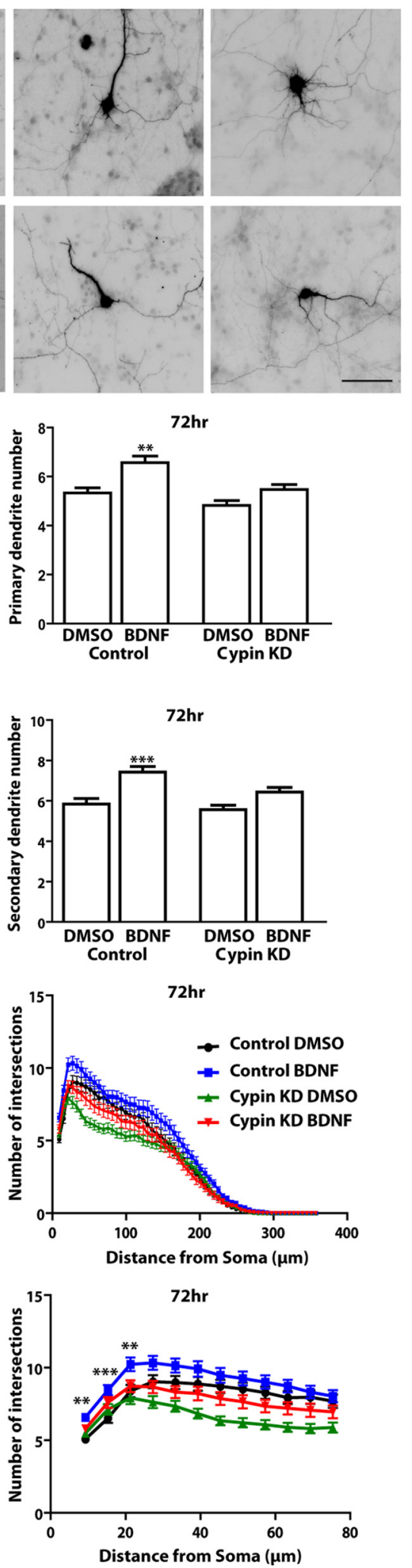

Figure 2. BDNF treatment results in increased proximal dendrites via a cypin-dependent pathway. $\boldsymbol{A}$, Hippocampal neurons were transfected with shRNA against GST (control) or with shRNA against cypin at 5 DIV and treated with either DMSO (vehicle) or BDNF (25 ng/ml) at 7 DIV for either 5 or $72 \mathrm{~h}$. Dendrite number was assessed at 7 or 10 DIV. Scale bar, $100 \mu \mathrm{m}$. B, C, Cypin knockdown (KD) blocks BDNF-promoted increases in primary dendrites $(\boldsymbol{B})$ and secondary dendrites $(\boldsymbol{C})$ with $72 \mathrm{~h}$ of treatment (right). BDNF treatment for $5 \mathrm{~h}$ does not increase dendrite numbers (left). ${ }^{* * *} p<0.001,{ }^{* *} p<0.01$, comparing control shRNA plus BDNF $72 \mathrm{~h}$ treatment to control shRNA with DMSO $72 \mathrm{~h}$ treatment and no significance comparing cypin knockdown plus DMSO $72 \mathrm{~h}$ treatment and cypin knockdown plus BDNF $72 \mathrm{~h}$ treatment. $p$ values were determined by Kruskal-Wallis test followed by

propanesulfonic acid, $50 \mathrm{~mm} \beta$-glycerolphosphate, $50 \mathrm{~mm}$ sodium fluoride, $1 \mathrm{~mm}$ sodium vanadate, 5 mm EGTA, 2 mm EDTA, 1\% NP-40, 1 mM DTT, and 1 mM PMSF. Insoluble material was pelleted at $12,000 \times g$ at $4^{\circ} \mathrm{C}$ for 15 min. Lysates were assayed following the manufacturer's instructions. Samples were added to plates precoated with PKA substrate, and ATP was added to the reactions. After $90 \mathrm{~min}$ incubation at $30^{\circ} \mathrm{C}$, phospho-specific substrate antibody was added, and the plate was incubated for $1 \mathrm{~h}$. The plate was washed four times, and a secondary antibody conjugated with HRP was applied. After 30 min incubation, the plate was washed and TMB substrates were added followed by the addition of Stop solution. The absorbance was measured at $450 \mathrm{~nm}$ using a SpectraMax 250 microplate reader (Molecular Devices)

Transfection of cultured cells. Cultured hippocampal neurons were transfected 5 DIV for shRNAs and 6 DIV for cDNAs using Lipofectamine LTX with Plus reagent following the manufacturer's protocol (Invitrogen).

Immunocytochemistry. Neurons were fixed in 4\% paraformaldehyde in PBS for 15 min and then incubated in blocking solution (PBS containing $0.1 \%$ Triton $\mathrm{X}-100,2 \%$ normal goat serum, and $0.02 \%$ sodium azide) for $1 \mathrm{~h}$. All antibodies used were diluted in blocking solution, and dilutions of 1:500 for chicken antiGFP, anti-MAP2, and anti-cypin were used. Neurons were incubated in primary antibodycontaining solution at $4^{\circ} \mathrm{C}$ overnight. Neurons were then washed with PBS three times. The secondary antibody solution consisted of a 1:250 dilution of Cy2-conjugated anti-chicken IgY, Cy3-conjugated anti-mouse IgG, and Cy-5 conjugated anti-rabbit IgG. Coverslips were then mounted onto frosted glass microscope slides using Fluoromount G (Southern Biotechnology). Labeled cells were visualized by immunofluorescence on an Olympus Optical IX50 microscope with a Cooke SensiCam charge-coupled device (CCD) cooled camera

$\leftarrow$

Dunn's multiple comparison test. $D$, Sholl analysis. BDNF treatment for $72 \mathrm{~h}$ increases the number of intersections close to the soma (proximal dendrites) $\boldsymbol{E}$, Proximal Sholl analysis (from D) within the first $75 \mu \mathrm{m}$ of the soma. $\left({ }^{*} p<0.05\right.$ at $9 \mu \mathrm{m}$, ${ }^{* * *} p<0.001$ at $15 \mu \mathrm{m},{ }^{* *} p<0.01$ at $33 \mu \mathrm{m}$ when comparing control shRNA plus BDNF $72 \mathrm{~h}$ treatment and control shRNA plus DMSO $72 \mathrm{~h}$ treatment and no significance when comparing cypin knockdown plus DMSO $72 \mathrm{~h}$ treatment and cypin knockdown with BDNF $72 \mathrm{~h}$ treatment. Cypin knockdown results in a significant decrease $\left({ }^{* * *} p<0.001\right)$ in intersections in comparison to control shRNA, consistent with our previous work. $p$ values were determined by two-way ANOVA followed by Bonferroni multiple-comparisons test. Error bars indicate SEM. $n=51$ neurons, control shRNA plus DMSO $5 \mathrm{~h}$ treatment; $n=40$, control shRNA plus BDNF $5 \mathrm{~h}$ treatment; $n=48$, cypin knockdown plus DMSO 5 h treatment; $n=52$, cypin knockdown plus BDNF $5 \mathrm{~h}$ treatment; $n=76$, control shRNA plus DMSO $72 \mathrm{~h}$ treatment; $n=79$, control shRNA plus BDNF $72 \mathrm{~h}$ treatment; $n=90$, cypin knockdown plus DMSO $72 \mathrm{~h}$ treatment; and $n=87$, cypin knockdown plus BDNF $72 \mathrm{~h}$ treatment. 
fluorescence imaging system and Image Pro software (Media Cybernetics).

Assessment of dendrite number. Dendrite morphology was processed as described previously (Kutzing et al., 2010; Langhammer et al., 2010) using custom scripts written in MATLAB (MathWorks. The axon was excluded based on the absence of MAP2 immunostaining. We performed Sholl analysis with a $6 \mu \mathrm{m}$ ring interval starting at $9.3 \mu \mathrm{m}$ from the soma. The experimenter was blinded to conditions during all data analysis. Dendrites less than $3 \mu \mathrm{m}$ in length were not counted ( $\mathrm{Yu}$ and Malenka, 2004; Charych et al., 2006).

Chromatin immunoprecipitation. At 7 DIV, neurons were treated with $25 \mathrm{ng} / \mathrm{ml} \mathrm{rhBDNF}$ and DMSO for $24 \mathrm{~h}$. Cells were treated with $1 \%$ formaldehyde at $37^{\circ} \mathrm{C}$ for $10 \mathrm{~min}$ to cross-link histones to DNA. After washing the cells twice with ice-cold PBS containing protease inhibitors, cells were scraped and pelleted at 2000 $\mathrm{rpm}$ at $4^{\circ} \mathrm{C}$ for $4 \mathrm{~min}$. The pellet was resuspended in SDS lysis buffer (1\% SDS, $10 \mathrm{~mm}$

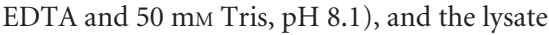
was sonicated. After centrifuging the lysates at $12,000 \times g$ at $4^{\circ} \mathrm{C}$ for $10 \mathrm{~min}$, the supernatant was diluted in chromatin immunoprecipitation (ChIP) dilution buffer (Millipore). Lysate was precleared with salmon sperm DNA/protein A agarose $50 \%$ slurry for $1 \mathrm{~h}$ and then immunoprecipitated with monoclonal CREB antibody or mouse $\operatorname{IgG}$ at $4^{\circ} \mathrm{C}$ overnight. Salmon sperm DNA/protein A agarose slurry was added for $1 \mathrm{~h}$ of incubation, and beads were washed one time each with MilliporeLow Salt Immune Complex Wash Buffer, zcomMilliporeHigh Salt Immune Complex Wash Buffer, MilliporeLiCl Immune Complex Wash Buffer, and then twice with TE buffer (10 mM Tris- $\mathrm{HCl}, 1 \mathrm{~mm}$ EDTA). Immunoprecipitated histone complex was eluted with elution buffer ( $1 \%$ SDS, $\left.0.1 \mathrm{M} \mathrm{NaHCO}_{3}\right) . \mathrm{NaCl}(5 \mathrm{~m})$ was added to the eluates, followed by heating at $65^{\circ} \mathrm{C}$ for $4 \mathrm{~h}$. After $1 \mathrm{~h}$ incubation with proteinase $\mathrm{K}$, the DNA was recovered by phenol/ chloroform extraction and ethanol precipitation. PCR was performed with following primers: forward, 5'-GAG GAC TTT AGA CTG GAA ACT TGC AAT TGG-3'; reverse, $5^{\prime}$-TTC CTG AGT GTG AGG GAT GCT GAC TAT G-3'.

Quantification of fluorescence intensity. Hippocampal neurons were prepared, cultured, and transfected as described above. The neurons were immunostained using our polyclonal antibody against cypin. Fluorescence intensities of cypin were measured using Image J software as we have described previously (Chen and Firestein, 2007). Briefly, the cell bodies for each neuron were traced, and intensities were measured as integrated pixel intensity within the selected region corrected for background. Fluorescence was visualized using an Olympus LC Plan FL $20 \times / 0.4$ (air) objective. To quantitate the fluorescence levels of endogenous proteins, images of neurons were captured by a CCD camera as described above (see Immunohistochemistry) using a constant gain and exposure time for all samples. Images were corrected for coverslip fluorescence by subtracting a background image generated using an $11 \times 11$ erosion filter. The experimenter was blinded to the condition when taking images and assaying fluorescence intensities. iments for all panels.
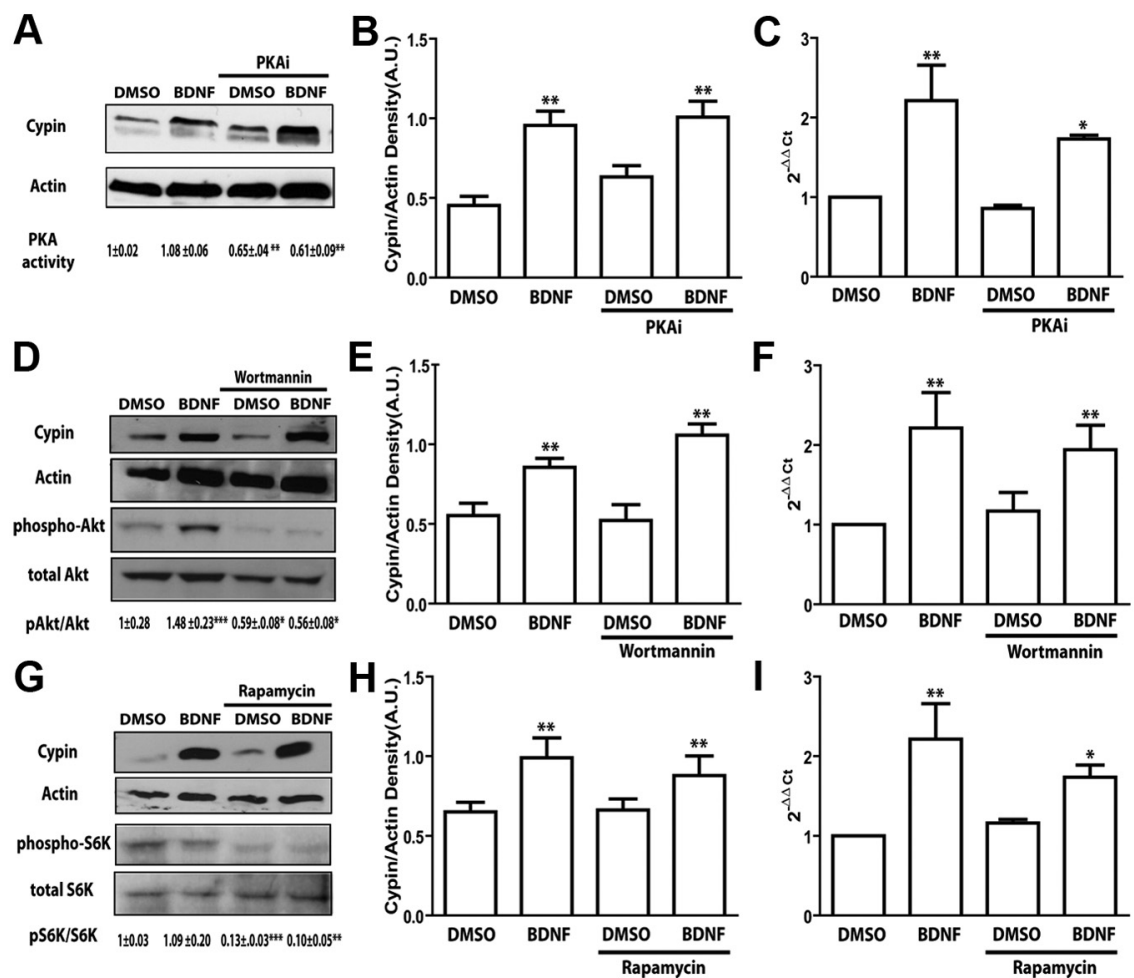

Figure 3. The CAMP/PKA, PI3K/Akt/PKB, and mTOR pathways are not involved in BDNF-mediated increases in cypin expression. $\boldsymbol{A}-\boldsymbol{I}$, Hippocampal neurons were treated with membrane-permeable PKA inhibitory (PKAi) peptide (25 ng/ml; Myr-N-Gly-ArgThr-Gly-Arg-Arg-Asn-Ala-Ile-NH $\left.{ }_{2}\right)(\boldsymbol{A}-\boldsymbol{C})$, wortmannin (100 nм) $(\boldsymbol{D}-\boldsymbol{F})$, or rapamycin (25 ng/ml) $(\boldsymbol{G}-\boldsymbol{I})$ at 7 DIV and treated with BDNF for $72 \mathrm{~h}$. Cytoplasmic protein extracts were resolved by SDS-PAGE and Western blotting using antibodies that recognize indicative proteins. PKA activity was measured by absorbance at $450 \mathrm{~nm}$ with an ELISA-based PKA activity assay. PKA activity is shown as mean normalized absorbance \pm SEM. Densitometric analysis of active phospho-proteins normalized to total proteins are indicated as mean \pm SEM. Densitometric analysis of cypin is normalized to actin protein expression. Extracts from treated cultures were then analyzed by quantitative RT-PCR using specific rat cypin/GDA primers. ${ }^{*} p<0.05,{ }^{* *} p<0.01,{ }^{* * *} p<0.001$ by ANOVA followed Student-Newman-Keuls multiple-comparison test compared to DMSO as vehicle control. Error bars indicate SEM. $n=3$ experiments for all panels with representative blots shown in $\boldsymbol{A}, \mathbf{D}, \mathbf{G}$. S6K, p70S6 kinase.
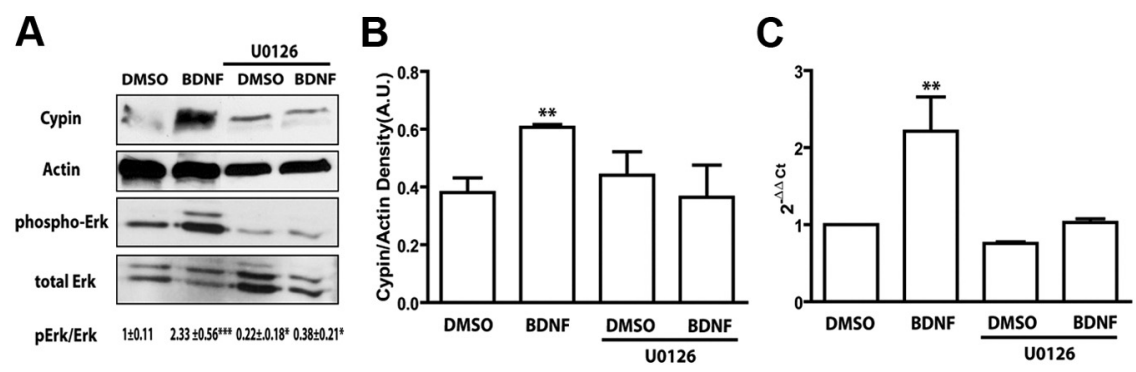

Figure 4. BDNF increases cypin expression via the MAPK signaling pathway. $\boldsymbol{A}$, Hippocampal neurons were treated with DMSO or $10 \mathrm{~nm}$ U0126, a MEK inhibitor, which consequently inhibits MAPK, in the absence or presence of $25 \mathrm{ng} / \mathrm{mI} \mathrm{BDNF}$ on DIV 7 for $72 \mathrm{~h}$. Representative Western blots using antibodies that recognize cypin, actin, phospho-Erk1/2, and total Erk1/2 are shown. Densitometric analysis of active MAPK normalized to total MAPK is indicated as mean \pm SEM. $\boldsymbol{B}$, Densitometric analysis of cypin is normalized to actin protein expression. C, Quantitative RT-PCR using specific rat cypin primers. ${ }^{*} p<0.05,{ }^{* *} p<0.01,{ }^{* * *} p<$ 0.001 by ANOVA followed Student-Newman-Keuls multiple-comparison test compared to DMSO as vehicle control. $n=3$ exper-

\section{Results \\ BDNF increases cypin protein levels in hippocampal neurons To investigate the possibility that neurotrophic factors may mod- ulate cypin expression to promote increases in dendrite number, we treated cultures of primary hippocampal neurons with three neurotrophins: nerve growth factor, brain-derived neurotrophic factor, and neurotrophin-3. These neurotrophins have a degree of receptor specificity when applied at low levels, with NGF bind-}


ing to TrkA, BDNF and NT-4/5 binding to TrkB, and NT- 3 preferentially binding to TrkC (Reichardt, 2006). We investigated the role of these neurotrophins in promoting changes in cypin expression by examining mRNA levels with quantitative RT-PCR (qRT-PCR) and protein levels with Western blotting. Since different concentrations of neurotrophins can have different affinities for Trk receptors (Davies et al., 1993; Mahadeo et al., 1994), we used two different concentrations of each neurotrophin. Only exposure to BDNF significantly increases cypin mRNA and protein levels after $72 \mathrm{~h}$ of treatment (Fig. $1 A-C$ ). This increase is dose dependent and is due to TrkB activation, because at the concentrations tested no apparent cross-stimulation of TrkA, TrkC, or p75 should occur (Ji et al., 2005). Furthermore, since it has been reported that exposure of cortical neurons to BDNF for as little as $5 \mathrm{~h}$ is sufficient to increase the number of primary dendrites (Dijkhuizen and Ghosh, 2005), and TrkB is maximally phosphorylated in 5 min by $25 \mathrm{ng} / \mathrm{ml}$ BDNF (Ji et al., 2005), we tested whether a shorter exposure of hippocampal neurons to BDNF results in this increase in cypin expression. As seen in Figure $1 D, 72 \mathrm{~h}$ is the minimum time of BDNF exposure needed to see the increase in cypin expression. It should be noted that cypin levels increase as neurons mature in culture (Kuwahara et al., 1999), and thus we observed this baseline increase in cultures treated with DMSO. Thus, we used a $72 \mathrm{~h}$ incubation time for the rest of our studies, acknowledging the fact that we are studying pathways involved in longer term exposure to BDNF rather than a short pulse of BDNF exposure.

\section{BDNF signals through cypin to increase dendrite numbers}

To determine whether BDNF signals via cypin to regulate dendrite patterning, we used an shRNA against cypin as we have described previously and shown to be specific for cypin by rescue experiments (Chen and Firestein, 2007). Consistent with results from other laboratories (Dijkhuizen and Ghosh, 2005), BDNF increases primary and secondary dendrite numbers in neurons treated during DIV 7-10 in the presence of the expression of a control shRNA. However, we did not see changes in dendrite number in our hippocampal neurons in response to shorter exposures of BDNF as has been seen in cortical neurons (Dijkhuizen and Ghosh, 2005), which is in line with a previous report showing that pathways that control dendrite outgrowth differ between cortical and hippocampal neurons (Ko et al., 2005). As seen in Figure $2 A$ and $B$, knockdown of cypin blocks increases in primary and secondary dendrite numbers in response to $72 \mathrm{~h}$ treatment with BDNF. We also observed some pruning in primary dendrite number from DIV 7-10, consistent with previous results (Cline, 2001; Wong and Ghosh, 2002; Charych et al., 2006). In addition, we performed Sholl analysis by measuring the number of dendrites that cross ellipsoids at different radial distances from the cell body to analyze the roles of BDNF and cypin in higher-order dendritic branching (Fig. 2D). Sholl analysis shows that treatment with BDNF for $72 \mathrm{~h}$ results in an increase in dendrite numbers proximal to the soma, the $75 \mu \mathrm{m}$ region closest to the cell body (Fig. 2E). In contrast, this treatment with BDNF does not increase dendrites when cypin is knocked down, strongly suggesting that BDNF promotes dendrite branching via cypin at DIV 7-10. We also noted that knocking down cypin at an earlier time window, DIV 5-7 (for the $5 \mathrm{~h}$ treatment) (Fig. 2D,E), has no effect on dendrite numbers, suggesting that cypin may not regulate neurite outgrowth in early stages of development.

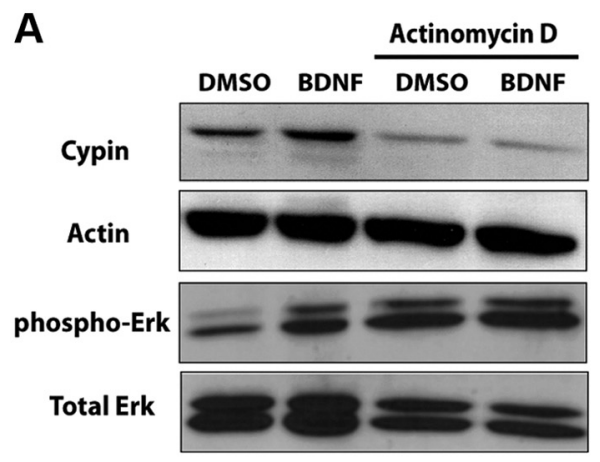

B


Figure 5. BDNF promotes cypin expression via a transcription-dependent mechanism. $\boldsymbol{A}$, Cultured hippocampal neurons were treated with $25 \mathrm{ng} / \mathrm{ml}$ BDNF concurrent with or without 5 $\mu \mathrm{m}$ actinomycin D at $7 \mathrm{DIV}$ for $72 \mathrm{~h}$. Proteins were extracted at $10 \mathrm{DIV}$, and Western blotting was performed using a cypin antibody. A representative blot is shown. $\boldsymbol{B}$, Densitometric analysis of cypin protein expression normalized to actin protein expression is shown. ${ }^{*} p<0.05$ by Kruskal-Wallis test followed by Dunnett's multiple-comparison test compared to untreated control. C, Quantitative RT-PCR using specific rat cypin/GDA primers. D, Densitometric analysis of phospho-Erk1/2 protein levels normalized to total Erk $1 / 2$ protein levels is shown. ${ }^{* *} p<0.01$ by ANOVA followed Student-Newman-Keuls multiple-comparison test compared to DMSO as control. $n=3$ experiments.

The cAMP/PKA pathway is not required for BDNF-promoted increases in cypin expression

We performed experiments to further identify the downstream pathways that mediate BDNF-promoted cypin gene expression. TrkB receptors dimerize in response to $\mathrm{BDNF}$ and phosphorylate one another. These phosphotyrosines generate binding sites for 

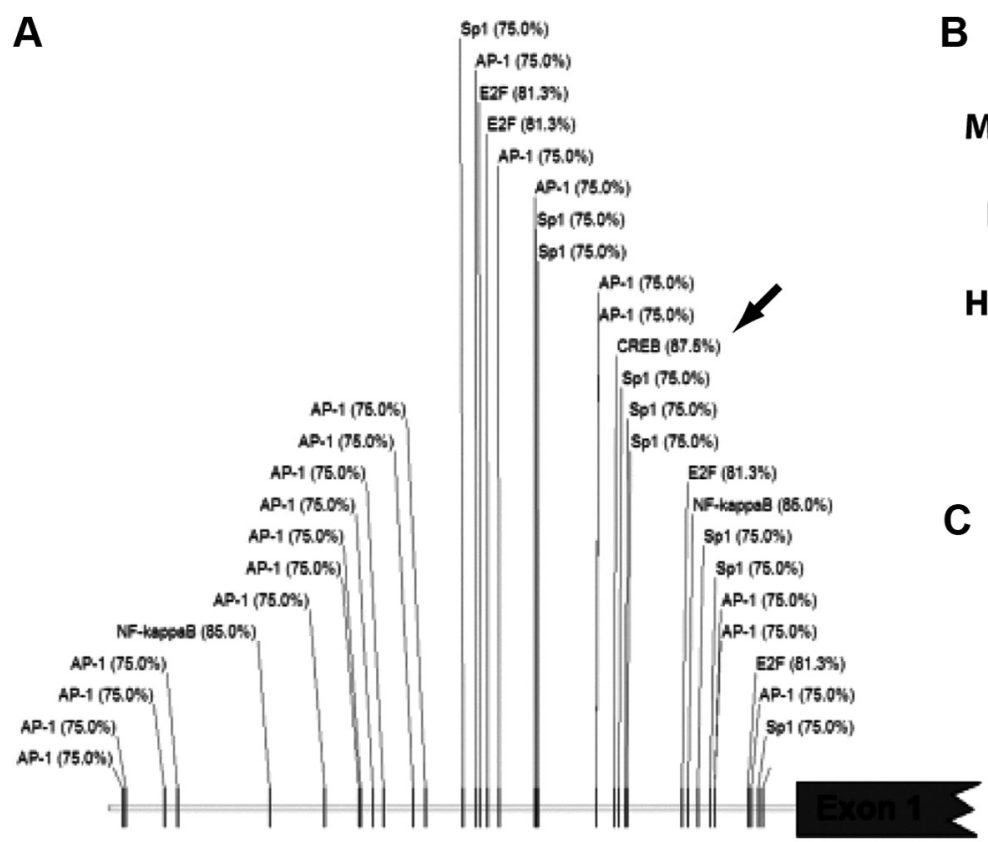

B
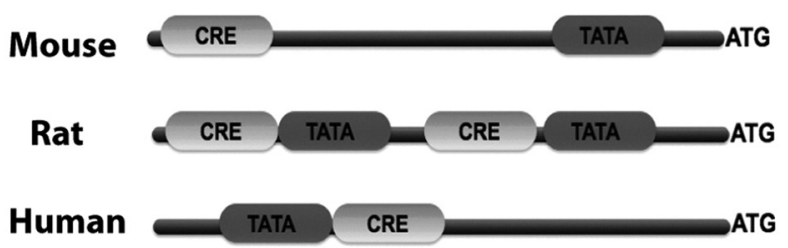

C

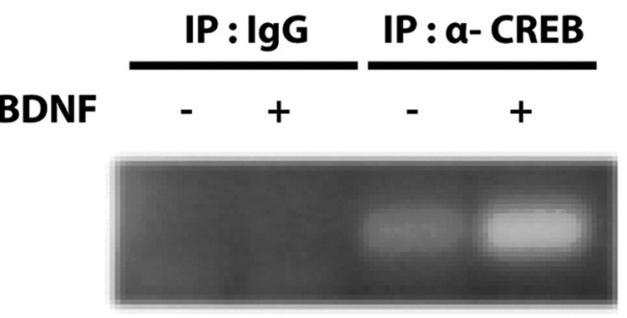

Figure 6. BDNF increases CREB binding to the cypin promoter. $A$, Prediction of transcription factor binding sites in the promoter region of rat cypin. The $10 \mathrm{~kb}$ upstream sequence of the first exon of cypin was used to predict consensus binding sequences using the TF Search algorithm and TRANSFAC database (Heinemeyer et al., 1998). Each position is represented by the transcription factor, and the binding probability (expressed as percentage of identity) is indicated as predicted by TFSearch-specific matrices. B. Conserved CRE regions are present in rodent and human cypin gene promoters. Genomic sequences from mouse, rat, and human were retrieved from the NCBI database up to $2 \mathrm{~kb}$ upstream from the first exon of cypin. These sequences were analyzed for the occurrence of conserved CRE and TATA box regions. C, Hippocampal neurons were treated with $25 \mathrm{ng} / \mathrm{ml}$ BDNF on DIV $7 \mathrm{for} 24 \mathrm{~h}$. Chromatin was isolated on DIV 8, and ChIP was performed using specific primers to the cypin promoter. $n=3$ experiments. A representative ChIP is shown.

Shc and phospholipase $\mathrm{C}$, which can recruit the signaling molecules to trigger activation of major pathways, such as cAMP/PKA, phosphoinositide 3-kinase (PI3K), mammalian target of rapamycin (mTOR), and MAPK signaling pathways (Chao, 2003; Segal, 2003; Kumar et al., 2005; Spencer et al., 2008). Therefore, we first tested the possibility that BDNF-mediated increases in cypin expression are mediated by the cAMP/PKA pathway. We treated cultured hippocampal neurons with a myristoylated membranepermeable PKA inhibitor peptide and assessed BDNF action on cypin expression. Inhibition of PKA (Fig. $3 A$, bottom) does not block BDNF-promoted increases in cypin mRNA or protein (Fig. $3 A-C)$. These results suggest that the activation of PKA by BDNF is not required for increased cypin expression. Interestingly, the appearance of a lower molecular weight band in our Western blot analysis suggests that the CAMP signaling pathway may alter expression of a lower molecular weight cypin variant (data not shown).

The PI3K-Akt-mTOR pathway is not required for BDNFpromoted increases in cypin expression

Given that the cAMP/PKA pathway appears not to be involved in BDNF-promoted expression of cypin in neurons, we further tested other signaling pathways reported to be activated by BDNF. PI3K/Akt pathways are triggered by BDNF to regulate primary dendrite formation in cortical neurons (Dijkhuizen and Ghosh, 2005). In addition, there are several studies that support the idea that BDNF can regulate dendrite branching through the PI3K pathway by activating mTOR (Schratt et al., 2004; Jaworski et al., 2005; Kumar et al., 2005). Therefore, we tested the possibility that BDNF uses these pathways to increase cypin expression. We treated cultured neurons with wortmannin and rapamycin, potent and specific PI3 kinase and mTOR inhibitors, respectively. We then measured cypin mRNA and protein ex- pression. Inhibition of PI3K (Fig. 3D, bottom) or the mTOR (Fig. $3 G$, bottom) does not affect BDNF-mediated increases in cypin mRNA or protein expression (Fig. $3 D-F, G-I$ ), suggesting that the activation of PI3K/Akt and mTOR by BDNF is not required for increased cypin expression.

\section{The MAPK signaling pathway is responsible for increased} cypin expression in hippocampal neurons

The Ras/MAPK pathways have also been reported to mediate BDNF-mediated increases in primary dendrite number in cortical neurons (Kumar et al., 2005). To test the involvement of MAPK in BDNF-mediated increases in cypin expression, we used the highly selective MAP kinase kinase (MAPK/MEK) inhibitor U0126 (Favata et al., 1998). As seen in Figure 4, U0126 inhibits BDNF-promoted increases in cypin mRNA and protein overexpression. These results suggest that BDNF specifically increases cypin protein expression in hippocampal neurons via activation of the MAPK signaling pathway.

\section{BDNF treatment increases cypin expression via a} transcription-dependent mechanism

Because BDNF not only increases cypin protein levels but also cypin mRNA levels, and MAPK pathways can trigger the activation of transcription factors to perform various mechanisms of cellular action, we hypothesized that BDNF promotes cypin expression in a transcription-dependent manner. We used a pharmacological drug, actinomycin $\mathrm{D}$, to inhibit transcription by binding DNA at the transcription initiation complex and preventing elongation of transcription by the RNA polymerase (Sobell, 1985). As shown in Figure 5, actinomycin D treatment blocks BDNF-mediated increases in cypin mRNA and protein levels. We then tested the possibility that actinomycin D acts by decreasing MAPK activity, which would lead to decreased cypin 

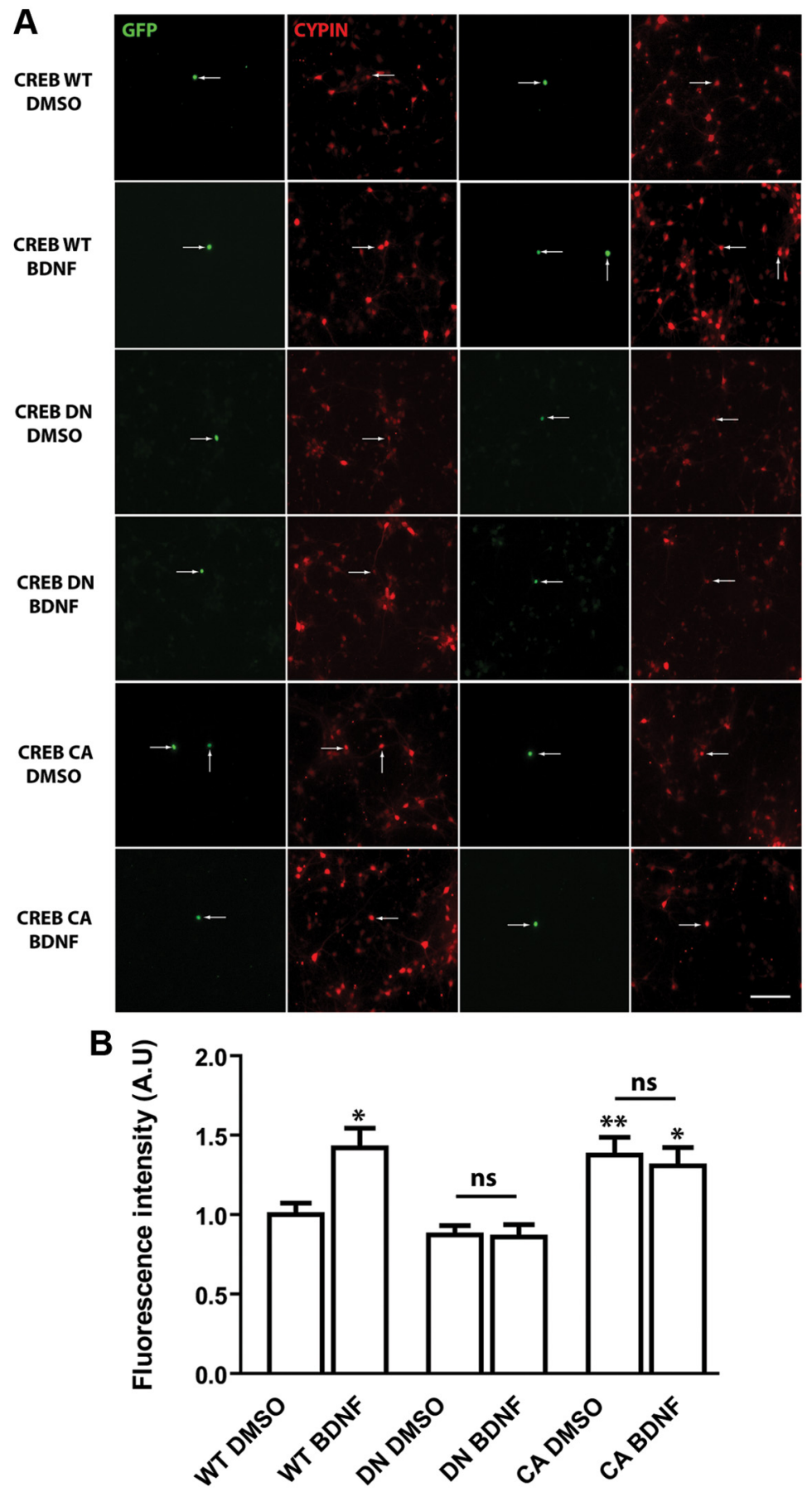

Figure 7. Expression of a dominant negative mutant or a constitutively active mutant of CREB attenuates BDNF-promoted increases in cypin expression. $A$, Hippocampal neurons were transfected with pEGFP-CREB WT (wild type, control) vector (control) with pEGFP-CREB DN (dominant negative form, Ser119Ala) or pEGFP-CREB CA (constitutively active form, Ser119Asp) at 6 DIV and treated with either DMSO (vehicle) or BDNF $(25 \mathrm{ng} / \mathrm{ml})$ at 7 DIV for $72 \mathrm{~h}$. Neurons were immunostained using a polyclonal cypin antibody. Arrows point to transfected neurons. Scale bar, $100 \mu \mathrm{m}$. B, Average fluorescence intensity (A.U., Arbitrary units) of cypin immunostaining was assessed in individual cells. Expression of CREB DN blocks and expression of CREB CA occludes BDNF-promoted increases in cypin expression. $n=20$ neurons for each condition, ${ }^{*} p<0.05,{ }^{* *} p<0.01$ by ANOVA followed by StudentNewman-Keuls multiple-comparison test compared to DMSO-treated neurons expressing CREB WT. ns, No significance compared to DMSO-treated neurons.

levels, rather than by directly blocking BDNF-promoted transcription of cypin. This is not the case, as we found the opposite effect of actinomycin D. Actinomycin increases MAPK activity (Fig. $5 A, D$ ), suggesting that actinomycin D may inhibit the transcription of inhibitors of MAPK and that MAPK activity is up- stream of BDNF-promoted increases in cypin transcription. Together with our other results, these data suggest that BDNF increases dendrite number by upregulating cypin transcription and, ultimately, cypin translation.

\section{BDNF increases CREB binding to the cypin gene promoter}

To identify possible cis-acting regulators of the cypin gene promoter, we performed a bioinformatics-based analysis to predict regulatory binding regions. Because the minimal promoter region of the rodent or human promoter region of cypin has not yet been characterized, we analyzed a vast region upstream of the first exon start region $(10 \mathrm{~kb})$. We compiled a list of predicted transcription factors consisting of AP-1, Sp-1, E2F, NF- $\kappa$ B, and CREB that may bind to a regulatory region of the $c y$ pin gene (Fig. $6 A$ ). Both NF- $\kappa$ B and CREB obtained higher binding probability than the other factors, and thus we analyzed whether there is conservation of these regions between rodent and human genes. CRE regions were conserved between the mouse, rat, and human cypin genes as shown in Fig. $6 B$, although the positions of these regions differed within the gene. In addition, distinct TATA box domains were also found in this region and in proximity to the CRE elements, suggesting that together these domains may represent an important regulatory region of the cypin gene. To assess whether CREB is involved in BDNF-promoted increases in cypin transcription, we performed a chromatin immunoprecipitation assay. We found that CREB binds to the cypin promoter under basal conditions and that this binding is enhanced by extracellular treatment of BDNF (Fig. 6C). Together, these data suggest that BDNF increases CREB binding to the cypin promoter to promote transcription of the cypin gene.

BDNF activates CREB to increase cypin expression and dendrite branching CREB is activated by its phosphorylation at Ser119 (equivalent position to Ser133 in CREB-341 isoform B, NCBI accession no. NP112279.1) to promote cellular gene expression, and this Ser119 phosphorylation of CREB is sufficient to recruit CBP-RNA polymerase II complexes and activate transcription of gene expression (Nakajima et al., 1997). We used a dominant negative mutant of CREB (CREB DN), in which serine119 is mutated to alanine and cannot be phosphorylated, to further investigate the role of CREB in BDNF-mediated increases in cypin and dendrite number. Wild-type CREB (CREB WT) was used as a control, and BDNF treatment increased cypin expression in 
neurons expressing CREB WT (Fig. 7 A, B). Expression of CREB DN blocked BDNF-promoted increases in cypin expression (Fig. $7 A, B)$. We then tested whether CREB activation is sufficient to increase cypin levels. We used a constitutively active mutant of CREB (CREB CA) in which serine119 is mutated to aspartate to mimic the phosphorylated state. Neurons that express CREB CA showed increased cypin protein levels. Furthermore, expression of CREB CA occludes BDNF-induced increases in cypin expression. Our data strongly suggest that BDNF activates CREB, which in turn increases cypin expression. We further investigated whether BDNF regulates dendritogenesis via CREB activation. Neurons were cotransfected with a DsRed-tagged CREB DN construct and enhanced GFP-containing vector to assess dendrite number. Sholl analysis shows that neurons that express CREB DN do not show increased proximal dendrite numbers when exposed to BDNF (Fig. 8). Our data support the idea that BDNF activates CREB to increase the expression of cypin and, as a result, proximal dendrite numbers.

\section{Discussion}

Dendrite number and branching are regulated by the interplay between extrinsic factors and intrinsic factors. Much progress has been made in identifying the key players and elucidating the signaling mechanisms that regulate dendrite morphology and patterning. There is a long list of external factors, including neurotrophins (for review, see McAllister et al., 1996; McAllister, 2000), estrogen (Audesirk et al., 2003; Sakamoto et al., 2003), and electrical activity (Vaillant et al., 2002). Some of the known intrinsic factors are the small GTPases RhoA, Rac1, and Cdc42 (Threadgill et al., 1997; Ruchhoeft et al., 1999; Li et al., 2000; Chen and Firestein, 2007), calcium/calmodulin-dependent protein kinase II (Fink et al., 2003), $\beta$-catenin (Yu and Malenka, 2004), CREST (Aizawa et al., 2004), Dishevelled (Rosso et al., 2005), some novel genes in Drosophila (Gao et al., 1999; Moore et al., 2002; Grueber et al., 2003; Emoto et al., 2004), cypin (Akum et al., 2004), and PSD-95 (Charych et al., 2006). Our laboratory has focused on cypin, a protein that regulates dendrite formation by promoting microtubule assembly and negatively regulates trafficking of PSD-95, which is associated with signaling networks at excitatory synapses and decreases dendrite branching. Our current studies are the first to demonstrate that extracellular factors, specifically BDNF, can regulate cypin gene expression.

Our results suggest that the MAPK pathway regulates BDNFmediated cypin expression in hippocampal neurons. This signaling cascade is involved in promoting neuritogenesis and neurite outgrowth via CREB-mediated gene expression (Tojima et al., 2003). Therefore, we suggest that cypin is a candidate gene that is regulated by this signaling pathway via activation of CREB. Our results support this hypothesis, since pharmacological data confirm that a MEK-specific inhibitor and expression of a dominant negative form of CREB block BDNF-mediated increases in cypin expression.

Because BDNF is an important molecule for dendrite growth, much work has focused on elucidating BDNF signaling pathways. Ligand binding to TrkB triggers a cascade of phosphorylation events. Phosphorylated tyrosine residues on the receptor allow for Shc and phospholipase C (PLC) to attach. PLC becomes phosphorylated and activated (Segal, 2003). In addition to PLC, TrkB can signal via the PI3K pathway. Tyrosine phosphorylation allows SHC and Grb2 to recruit PI3K as well as SOS. PI3K activates the AKT pathway, and SOS activates the Ras/MAPK cascade (Segal, 2003). In contrast, there are also several studies that support the idea that BDNF can regulate dendrite branching through
A

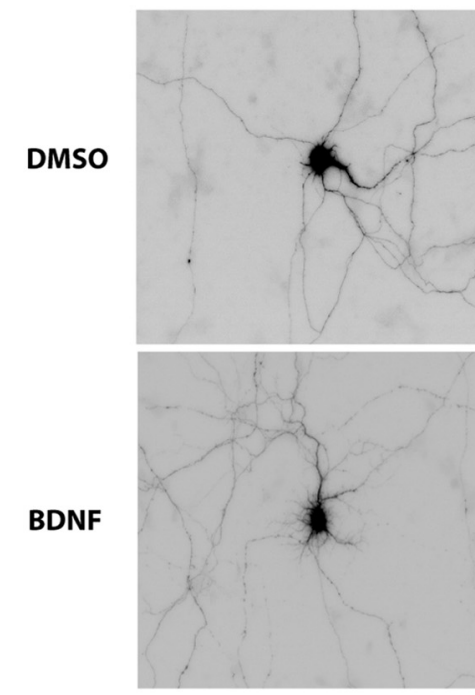

B

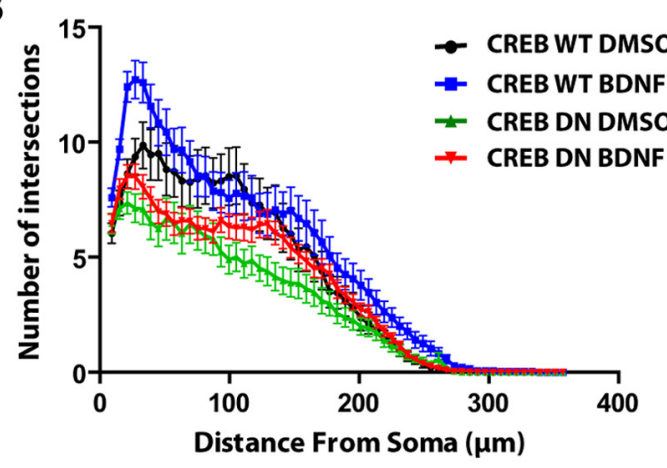

C

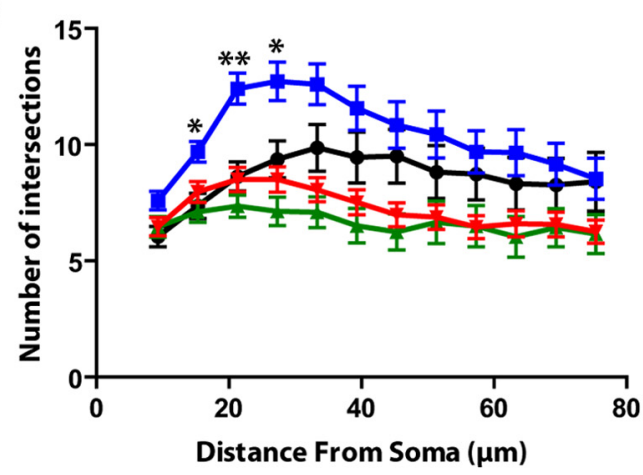

Figure 8. Expression of a dominant negative mutant of CREB attenuates BDNF-promoted increases in dendrite number. $\boldsymbol{A}$, Hippocampal neurons were cotransfected with pEGFP and either DsRed-CREB WT(control) or ds-Red-CREB DN at 6 DIV and treated with either DMSO (vehicle) or BDNF ( $25 \mathrm{ng} / \mathrm{ml}$ ) at 7 DIV for $72 \mathrm{~h}$. Representative GFP images are shown. Dendrite number was assessed at $10 \mathrm{DIV}$. Scale bar, $100 \mu \mathrm{m}$. B, Sholl analysis. CREB DN overexpression blocks BDNF-promoted increases in the number of intersections close to the soma (proximal dendrites). C, Proximal Sholl analysis (from $\boldsymbol{B}$ ) within the first $75 \mu \mathrm{m}$ of the soma. ${ }^{*} p<0.05$ at 15 and $27 \mu \mathrm{m},{ }^{* *} p<0.01$ at $21 \mu \mathrm{m}$ when comparing CREB WT plus BDNF to CREB WT plus DMSO and no significance when comparing CREB DN plus DMSO to CREB DN plus BDNF treatment. $p$ values were determined by two-way ANOVA followed by Bonferroni multiplecomparisons test. Error bars indicate SEM. $n=22$ neurons, CREB WT plus DMSO; $n=32$, CREB WT plus BDNF; $n=33$, CREB DN plus DMSO; $n=42$, CREB DN plus BDNF.

the PI3K pathway by activating the mTOR (Jaworski et al., 2005; Kumar et al., 2005), which can then activate the translation of a group of mRNAs (Schratt et al., 2004). In fact, local administration of BDNF to dendrites of cultured hippocampal neurons re- 
sults in mTOR-dependent phosphorylation of S6, which is involved in local protein synthesis (Takei et al., 2004). While this increased phosphorylation was observed within $5 \mathrm{~min}$ of stimulation, our studies were performed using longer treatment times, suggesting the possibility that the duration of BDNF influences the activation of different signaling pathways. Recent studies support this idea that there would be temporal and spatial regulation of signaling by BDNF in neurons and have shown that acute and gradual increases in BDNF give rise to differential expression of Homerl and Arc in cultured hippocampal neurons (Ji et al., 2010). Moreover, mRNAs with the same BDNF coding sequence but distinct 3' UTRs have distinct cellular localizations and function (An et al., 2008), increasing the possibility that BDNF regulates neuronal morphology and function via several distinct cellular mechanisms. Our studies support the idea that increases in proximal dendrites resulting in response to BDNF do not depend on the activation of either PI3K or mTOR (Fig. 3), suggesting an alternative pathway of activation for BDNF-mediated increases in cypin expression and proximal dendrites in $72 \mathrm{~h}$.

The MAPK signaling cascade, which can be activated by $\mathrm{BDNF}$, is involved in promoting neuritogenesis and neurite outgrowth via CREB-mediated gene expression (Tojima et al., 2003). Similarly, in cortical neurons, primary dendrite number is regulated by BDNF via MAPK signaling pathways, and this effect is independent of nascent protein synthesis (Dijkhuizen and Ghosh, 2005). This is in contrast to our results in hippocampal neurons, whereby BDNF increases cypin transcription and translation to regulate proximal dendrite number. These differences may be due to the fact that different neuronal types were studied. This idea is supported by recent evidence that neurite outgrowth is regulated differently in cortical and hippocampal neurons (Ko et al., 2005).

Differences in signal transduction pathways activated by hippocampal versus cortical neurons may also be due to the BDNF receptor that is activated. Like other neurotrophins, BDNF exists in two states: proteolytically processed, which is the active form that can bind Trk receptors, or unprocessed, which allows BDNF to bind with high affinity to p75NTR. Thus, the complex actions of BDNF on the dendritic arbor may be mediated, in part, by multiple receptors resulting from alternative splicing of TrkB. Three alternative splice variants of TrkB have been identified. The full-length TrkB.FL contains a cytoplasmic tyrosine kinase domain, which is responsible for autophosphorylation and clustering of the receptor when activated by BDNF (Chao, 2003; Segal, 2003). Two truncated isoforms, termed TrkB.T1 and TrkB.T2, which lack the cytoplasmic tyrosine kinase domains, have also been identified (Barbacid, 1994). TrkB.FL and TrkB.T2 are expressed exclusively in neurons, and TrkB.T1 is expressed in both neurons and non-neuronal cells (Frisén et al., 1993; Rudge et al., 1994; Armanini et al., 1995; Biffo et al., 1995; Wetmore and Olson, 1995). Importantly, in rat, expression of the TrkB.FL in the hippocampus is barely detectable at embryonic day 15 but increases throughout development to reach adult levels by postnatal day (P)5 (Muragaki et al., 1995). Conversely, TrkB.FL reaches adult levels in cortex by P0. In addition, TrkB.T1 is expressed in the hippocampus at low levels until birth and reaches adult levels by P10-15. The expression of TrkB.T1 in cortex is similar, but adult levels are reached between P10 and P20 (Muragaki et al., 1995). This difference in developmental expression pattern, which encompasses the developmental time points of our cultures, coupled with the fact that TrkB.FL controls proximal branching while TrkB.T1 increases elongation of distal dendrites in cortical culture (Yacoubian and Lo, 2000), may explain the different pathways activated by BDNF in our study and other studies. In addition, TrkB.FL can inhibit the effects of TrkB.T1 and vice versa when both receptors are overexpressed, adding an additional layer of receptor crosstalk (Yacoubian and Lo, 2000; Hartmann et al., 2004).

MAPK phosphorylates extracellular signal-regulated kinases (ERKs), and these activated ERKs phosphorylate CREB (Bonni et al., 1999). CREB has been characterized as a critical molecule for the transcriptional regulation of dendritic complexity (Redmond and Ghosh, 2005; Wayman et al., 2006). Loss of CREB function has been shown to impair dendrite growth and arborization of newborn hippocampal neurons (Jagasia et al., 2009). In line with these reports, we have found that cypin is a target gene for CREB regulation and that BDNF enhances the binding of CREB to the cypin promoter. Thus, we have demonstrated, by pharmacological and cell biological methods, that BDNF, an important extrinsic factor needed for normal neuronal development, activates CREB-mediated increases in the expression of cypin, an essential intrinsic regulator of microtubule assembly and dendrite arborization. Since BDNF is thought to play a role in the development of cognitive disorders (Zuccato et al., 2001; Neves-Pereira et al., 2002; Sklar et al., 2002; He et al., 2004; Schumacher et al., 2005; Strauss et al., 2005; Lynch et al., 2007; Nagahara et al., 2009; Peng et al., 2009), our results will add to our understanding of how dendrite arborization is disrupted in these disorders.

\section{References}

Aizawa H, Hu SC, Bobb K, Balakrishnan K, Ince G, Gurevich I, Cowan M, Ghosh A (2004) Dendrite development regulated by CREST, a calciumregulated transcriptional activator. Science 303:197-202.

Akum BF, Chen M, Gunderson SI, Riefler GM, Scerri-Hansen MM, Firestein BL (2004) Cypin regulates dendrite patterning in hippocampal neurons by promoting microtubule assembly. Nat Neurosci 7:145-152.

An JJ, Gharami K, Liao GY, Woo NH, Lau AG, Vanevski F, Torre ER, Jones KR, Feng Y, Lu B, Xu B (2008) Distinct role of long 3' UTR BDNF mRNA in spine morphology and synaptic plasticity in hippocampal neurons. Cell 134:175-187.

Armanini MP, McMahon SB, Sutherland J, Shelton DL, Phillips HS (1995) Truncated and catalytic isoforms of trkB are co-expressed in neurons of rat and mouse CNS. Eur J Neurosci 7:1403-1409.

Audesirk T, Cabell L, Kern M, Audesirk G (2003) Enhancement of dendritic branching in cultured hippocampal neurons by 17 beta-estradiol is mediated by nitric oxide. Int J Dev Neurosci 21:225-233.

Baker RE, Dijkhuizen PA, Van Pelt J, Verhaagen J (1998) Growth of pyramidal, but not non-pyramidal, dendrites in long-term organotypic explants of neonatal rat neocortex chronically exposed to neurotrophin-3. Eur J Neurosci 10:1037-1044.

Barbacid M (1994) The Trk family of neurotrophin receptors. J Neurobiol 25:1386-1403.

Barde YA, Edgar D, Thoenen H (1982) Purification of a new neurotrophic factor from mammalian brain. EMBO J 1:549-553.

Biffo S, Offenhäuser N, Carter BD, Barde YA (1995) Selective binding and internalisation by truncated receptors restrict the availability of BDNF during development. Development 121:2461-2470.

Bonni A, Brunet A, West AE, Datta SR, Takasu MA, Greenberg ME (1999) Cell survival promoted by the Ras-MAPK signaling pathway by transcription-dependent and -independent mechanisms. Science 286:1358-1362.

Carrel D, Du Y, Komlos D, Hadzimichalis NM, Kwon M, Wang B, Brzustowicz LM, Firestein BL (2009) NOS1AP regulates dendrite patterning of hippocampal neurons through a carboxypeptidase E-mediated pathway. J Neurosci 29:8248-8258.

Chao MV (2003) Neurotrophins and their receptors: a convergence point for many signalling pathways. Nat Rev Neurosci 4:299-309.

Chao W, Liu H, Hanahan DJ, Olson MS (1992) Protein tyrosine phosphorylation and regulation of the receptor for platelet-activating factor in rat Kupffer cells. Effect of sodium vanadate. Biochem J 288:777-784.

Charych EI, Akum BF, Goldberg JS, Jörnsten RJ, Rongo C, Zheng JQ, Firest- 
ein BL (2006) Activity-independent regulation of dendrite patterning by postsynaptic density protein PSD-95. J Neurosci 26:10164-10176.

Chen H, Firestein BL (2007) RhoA regulates dendrite branching in hippocampal neurons by decreasing cypin protein levels. J Neurosci 27:8378-8386.

Cline HT (2001) Dendritic arbor development and synaptogenesis. Curr Opin Neurobiol 11:118-126.

Davies AM, Lee KF, Jaenisch R (1993) p75-deficient trigeminal sensory neurons have an altered response to NGF but not to other neurotrophins. Neuron 11:565-574.

Dijkhuizen PA, Ghosh A (2005) BDNF regulates primary dendrite formation in cortical neurons via the PI3-kinase and MAP kinase signaling pathways. J Neurobiol 62:278-288.

Emoto K, He Y, Ye B, Grueber WB, Adler PN, Jan LY, Jan YN (2004) Control of dendritic branching and tiling by the Tricornered-kinase/Furry signaling pathway in Drosophila sensory neurons. Cell 119:245-256.

Favata MF, Horiuchi KY, Manos EJ, Daulerio AJ, Stradley DA, Feeser WS, Van Dyk DE, Pitts WJ, Earl RA, Hobbs F, Copeland RA, Magolda RL, Scherle PA, Trzaskos JM (1998) Identification of a novel inhibitor of mitogen-activated protein kinase kinase. J Biol Chem 273:18623-18632.

Fernández JR, Welsh WJ, Firestein BL (2008) Structural characterization of the zinc binding domain in cytosolic PSD-95 interactor (cypin): Role of zinc binding in guanine deamination and dendrite branching. Proteins 70:873-881.

Fink CC, Bayer KU, Myers JW, Ferrell JE Jr, Schulman H, Meyer T (2003) Selective regulation of neurite extension and synapse formation by the beta but not the alpha isoform of CaMKII. Neuron 39:283-297.

Firestein BL, Brenman JE, Aoki C, Sanchez-Perez AM, El-Husseini AE, Bredt DS (1999) Cypin: a cytosolic regulator of PSD-95 postsynaptic targeting. Neuron 24:659-672.

Frisén J, Verge VM, Fried K, Risling M, Persson H, Trotter J, Hökfelt T, Lindholm D (1993) Characterization of glial trkB receptors: differential response to injury in the central and peripheral nervous systems. Proc Natl Acad Sci U S A 90:4971-4975.

Gao FB, Brenman JE, Jan LY, Jan YN (1999) Genes regulating dendritic outgrowth, branching, and routing in Drosophila. Genes Dev 13:2549-2561.

Grueber WB, Jan LY, Jan YN (2003) Different levels of the homeodomain protein cut regulate distinct dendrite branching patterns of Drosophila multidendritic neurons. Cell 112:805-818.

Hallböök F, Ibañez CF, Persson H (1991) Evolutionary studies of the nerve growth factor family reveal a novel member abundantly expressed in Xenopus ovary. Neuron 6:845-858.

Hartmann M, Brigadski T, Erdmann KS, Holtmann B, Sendtner M, Narz F, Lessmann V (2004) Truncated TrkB receptor-induced outgrowth of dendritic filopodia involves the p75 neurotrophin receptor. J Cell Sci 117:5803-5814

He XP, Kotloski R, Nef S, Luikart BW, Parada LF, McNamara JO (2004) Conditional deletion of TrkB but not BDNF prevents epileptogenesis in the kindling model. Neuron 43:31-42.

Heinemeyer T, Wingender E, Reuter I, Hermjakob H, Kel AE, Kel OV, Ignatieva EV, Ananko EA, Podkolodnaya OA, Kolpakov FA, Podkolodny NL, Kolchanov NA (1998) Databases on transcriptional regulation: TRANSFAC, TRRD and COMPEL. Nucleic Acids Res 26:362-367.

Horch HW, Krüttgen A, Portbury SD, Katz LC (1999) Destabilization of cortical dendrites and spines by BDNF. Neuron 23:353-364.

Jagasia R, Steib K, Englberger E, Herold S, Faus-Kessler T, Saxe M, Gage FH, Song H, Lie DC (2009) GABA-cAMP response element-binding protein signaling regulates maturation and survival of newly generated neurons in the adult hippocampus. J Neurosci 29:7966-7977.

Jaworski J, Spangler S, Seeburg DP, Hoogenraad CC, Sheng M (2005) Control of dendritic arborization by the phosphoinositide-3'-kinase-Aktmammalian target of rapamycin pathway. J Neurosci 25:11300-11312.

Ji Y, Pang PT, Feng L, Lu B (2005) Cyclic AMP controls BDNF-induced TrkB phosphorylation and dendritic spine formation in mature hippocampal neurons. Nat Neurosci 8:164-172.

Ji Y, Lu Y, Yang F, Shen W, Tang TT, Feng L, Duan S, Lu B (2010) Acute and gradual increases in BDNF concentration elicit distinct signaling and functions in neurons. Nat Neurosci 13:302-309.

Jin X, Hu H, Mathers PH, Agmon A (2003) Brain-derived neurotrophic factor mediates activity-dependent dendritic growth in nonpyramidal neocortical interneurons in developing organotypic cultures. J Neurosci 23:5662-5673.
Ko M, Zou K, Minagawa H, Yu W, Gong JS, Yanagisawa K, Michikawa M (2005) Cholesterol-mediated neurite outgrowth is differently regulated between cortical and hippocampal neurons. J Biol Chem 280:42759-42765.

Kumar V, Zhang MX, Swank MW, Kunz J, Wu GY (2005) Regulation of dendritic morphogenesis by Ras-PI3K-Akt-mTOR and Ras-MAPK signaling pathways. J Neurosci 25:11288-11299.

Kutzing MK, Langhammer CG, Luo V, Lakdawala H, Firestein BL (2010) Automated Sholl analysis of digitized neuronal morphology at multiple scales. J Vis Exp pii:2354.

Kuwahara H, Araki N, Makino K, Masuko N, Honda S, Kaibuchi K, Fukunaga K, Miyamoto E, Ogawa M, Saya H (1999) A novel NE-dlg/SAP102associated protein, $\mathrm{p} 51$-nedasin, related to the amidohydrolase superfamily, interferes with the association between NE-dlg/SAP102 and N-methyl-D-aspartate receptor. J Biol Chem 274:32204-32214.

Landgraf M, Evers JF (2005) Control of dendritic diversity. Curr Opin Cell Biol 17:690-696.

Langhammer CG, Previtera ML, Sweet ES, Sran SS, Chen M, Firestein BL (2010) Automated Sholl analysis of digitized neuronal morphology at multiple scales: Whole cell Sholl analysis versus Sholl analysis of arbor subregions. Cytometry A 77:1160-1168.

Levi-Montalcini R (1987) The nerve growth factor 35 years later. Science 237:1154-1162.

Levine ES, Dreyfus CF, Black IB, Plummer MR (1995) Brain-derived neurotrophic factor rapidly enhances synaptic transmission in hippocampal neurons via postsynaptic tyrosine kinase receptors. Proc Natl Acad Sci U S A 92:8074-8077.

Li Z, Van Aelst L, Cline HT (2000) Rho GTPases regulate distinct aspects of dendritic arbor growth in Xenopus central neurons in vivo. Nat Neurosci 3:217-225.

Libersat F (2005) Maturation of dendritic architecture: lessons from insect identified neurons. J Neurobiol 64:11-23.

Lynch G, Kramar EA, Rex CS, Jia Y, Chappas D, Gall CM, Simmons DA (2007) Brain-derived neurotrophic factor restores synaptic plasticity in a knock-in mouse model of Huntington's disease. J Neurosci 27:4424-4434.

Mahadeo D, Kaplan L, Chao MV, Hempstead BL (1994) High affinity nerve growth factor binding displays a faster rate of association than p140trk binding. Implications for multi-subunit polypeptide receptors. J Biol Chem 269:6884-6891.

Maisonpierre PC, Belluscio L, Squinto S, Ip NY, Furth ME, Lindsay RM, Yancopoulos GD (1990) Neurotrophin-3: a neurotrophic factor related to NGF and BDNF. Science 247:1446-1451.

McAllister AK (2000) Cellular and molecular mechanisms of dendrite growth. Cereb Cortex 10:963-973.

McAllister AK, Lo DC, Katz LC (1995) Neurotrophins regulate dendritic growth in developing visual cortex. Neuron 15:791-803.

McAllister AK, Katz LC, Lo DC (1996) Neurotrophin regulation of cortical dendritic growth requires activity. Neuron 17:1057-1064.

McAllister AK, Katz LC, Lo DC (1997) Opposing roles for endogenous BDNF and NT-3 in regulating cortical dendritic growth. Neuron 18:767-778

Miller JP, Jacobs GA (1984) Relationships between neuronal structure and function. J Exp Biol 112:129-145.

Moore AW, Jan LY, Jan YN (2002) hamlet, a binary genetic switch between single- and multiple- dendrite neuron morphology. Science 297:1355-1358.

Müller HW, Junghans U, Kappler J (1995) Astroglial neurotrophic and neurite-promoting factors. Pharmacol Ther 65:1-18.

Muragaki Y, Timothy N, Leight S, Hempstead BL, Chao MV, Trojanowski JQ, Lee VM (1995) Expression of trk receptors in the developing and adult human central and peripheral nervous system. J Comp Neurol 356:387-397.

Nagahara AH, Merrill DA, Coppola G, Tsukada S, Schroeder BE, Shaked GM, Wang L, Blesch A, Kim A, Conner JM, Rockenstein E, Chao MV, Koo EH, Geschwind D, Masliah E, Chiba AA, Tuszynski MH (2009) Neuroprotective effects of brain-derived neurotrophic factor in rodent and primate models of Alzheimer's disease. Nat Med 15:331-337.

Nakajima T, Uchida C, Anderson SF, Parvin JD, Montminy M (1997) Analysis of a cAMP-responsive activator reveals a two-component mechanism for transcriptional induction via signal-dependent factors. Genes Dev 11:738-747.

Neves-Pereira M, Mundo E, Muglia P, King N, Macciardi F, Kennedy JL 
(2002) The brain-derived neurotrophic factor gene confers susceptibility to bipolar disorder: evidence from a family-based association study. Am J Hum Genet 71:651-655.

Peng S, Garzon DJ, Marchese M, Klein W, Ginsberg SD, Francis BM, Mount HT, Mufson EJ, Salehi A, Fahnestock M (2009) Decreased brain-derived neurotrophic factor depends on amyloid aggregation state in transgenic mouse models of Alzheimer's disease. J Neurosci 29:9321-9329.

Redmond L, Ghosh A (2005) Regulation of dendritic development by calcium signaling. Cell Calcium 37:411-416.

Reichardt LF (2006) Neurotrophin-regulated signalling pathways. Philos Trans R Soc Lond B Biol Sci 361:1545-1564.

Rosso SB, Sussman D, Wynshaw-Boris A, Salinas PC (2005) Wnt signaling through Dishevelled, Rac and JNK regulates dendritic development. Nat Neurosci 8:34-42.

Ruchhoeft ML, Ohnuma S, McNeill L, Holt CE, Harris WA (1999) The neuronal architecture of Xenopus retinal ganglion cells is sculpted by rhofamily GTPases in vivo. J Neurosci 19:8454-8463.

Rudge JS, Li Y, Pasnikowski EM, Mattsson K, Pan L, Yancopoulos GD, Wiegand SJ, Lindsay RM, Ip NY (1994) Neurotrophic factor receptors and their signal transduction capabilities in rat astrocytes. Eur J Neurosci 6:693-705.

Sakamoto H, Mezaki Y, Shikimi H, Ukena K, Tsutsui K (2003) Dendritic growth and spine formation in response to estrogen in the developing Purkinje cell. Endocrinology 144:4466-4477.

Schratt GM, Nigh EA, Chen WG, Hu L, Greenberg ME (2004) BDNF regulates the translation of a select group of mRNAs by a mammalian target of rapamycin-phosphatidylinositol 3-kinase-dependent pathway during neuronal development. J Neurosci 24:7366-7377.

Schumacher J, Jamra RA, Becker T, Ohlraun S, Klopp N, Binder EB, Schulze TG, Deschner M, Schmäl C, Höfels S, Zobel A, Illig T, Propping P, Holsboer F, Rietschel M, Nöthen MM, Cichon S (2005) Evidence for a relationship between genetic variants at the brain-derived neurotrophic factor (BDNF) locus and major depression. Biol Psychiatry 58:307-314.

Schwartz PM, Borghesani PR, Levy RL, Pomeroy SL, Segal RA (1997) Abnormal cerebellar development and foliation in $\mathrm{BDNF}-/-$ mice reveals a role for neurotrophins in CNS patterning. Neuron 19:269-281.

Segal RA (2003) Selectivity in neurotrophin signaling: theme and variations. Annu Rev Neurosci 26:299-330.

Segal RA, Pomeroy SL, Stiles CD (1995) Axonal growth and fasciculation linked to differential expression of BDNF and NT3 receptors in developing cerebellar granule cells. J Neurosci 15:4970-4981.

Shooter EM (2001) Early days of the nerve growth factor proteins. Annu Rev Neurosci 24:601-629.

Sklar P, Gabriel SB, McInnis MG, Bennett P, Lim YM, Tsan G, Schaffner S,
Kirov G, Jones I, Owen M, Craddock N, DePaulo JR, Lander ES (2002) Family-based association study of 76 candidate genes in bipolar disorder: BDNF is a potential risk locus. Brain-derived neutrophic factor. Mol Psychiatry 7:579-593.

Sobell HM (1985) Actinomycin and DNA transcription. Proc Natl Acad Sci U S A 82:5328-5331.

Spencer TK, Mellado W, Filbin MT (2008) BDNF activates CaMKIV and PKA in parallel to block MAG-mediated inhibition of neurite outgrowth. Mol Cell Neurosci 38:110-116.

Strauss J, Barr CL, George CJ, Devlin B, Vetró A, Kiss E, Baji I, King N, Shaikh S, Lanktree M, Kovacs M, Kennedy JL (2005) Brain-derived neurotrophic factor variants are associated with childhood-onset mood disorder: confirmation in a Hungarian sample. Mol Psychiatry 10:861-867.

Takei N, Inamura N, Kawamura M, Namba H, Hara K, Yonezawa K, Nawa H (2004) Brain-derived neurotrophic factor induces mammalian target of rapamycin-dependent local activation of translation machinery and protein synthesis in neuronal dendrites. J Neurosci 24:9760-9769.

Threadgill R, Bobb K, Ghosh A (1997) Regulation of dendritic growth and remodeling by Rho, Rac, and Cdc42. Neuron 19:625-634.

Tojima T, Kobayashi S, Ito E (2003) Dual role of cyclic AMP-dependent protein kinase in neuritogenesis and synaptogenesis during neuronal differentiation. J Neurosci Res 74:829-837.

Vaillant AR, Zanassi P, Walsh GS, Aumont A, Alonso A, Miller FD (2002) Signaling mechanisms underlying reversible, activity-dependent dendrite formation. Neuron 34:985-998.

Wayman GA, Impey S, Marks D, Saneyoshi T, Grant WF, Derkach V, Soderling TR (2006) Activity-dependent dendritic arborization mediated by CaM-kinase I activation and enhanced CREB-dependent transcription of Wnt-2. Neuron 50:897-909.

Wetmore C, Olson L (1995) Neuronal and nonneuronal expression of neurotrophins and their receptors in sensory and sympathetic ganglia suggest new intercellular trophic interactions. J Comp Neurol 353:143-159.

Whitford KL, Dijkhuizen P, Polleux F, Ghosh A (2002) Molecular control of cortical dendrite development. Annu Rev Neurosci 25:127-149.

Wong RO, Ghosh A (2002) Activity-dependent regulation of dendritic growth and patterning. Nat Rev Neurosci 3:803-812.

Yacoubian TA, Lo DC (2000) Truncated and full-length TrkB receptors regulate distinct modes of dendritic growth. Nat Neurosci 3:342-349.

Yu X, Malenka RC (2004) Multiple functions for the cadherin/catenin complex during neuronal development. Neuropharmacology 47:779-786.

Zuccato C, Ciammola A, Rigamonti D, Leavitt BR, Goffredo D, Conti L, MacDonald ME, Friedlander RM, Silani V, Hayden MR, Timmusk T, Sipione S, Cattaneo E (2001) Loss of huntingtin-mediated BDNF gene transcription in Huntington's disease. Science 293:493-498. 